Squibb, UCB, Rene-Marc Flipo Consultant for: Advisory board: BristolMyers Squibb

DOI: 10.1136/annrheumdis-2019-eular.7476

\section{THU0163 A DESCRIPTIVE ANALYSIS OF LONGITUDINAL CHANGES IN RELATIVE MARKET SHARE PROPORTIONS OF BIOLOGIC AND TARGETED SYNTHETIC DISEASE-MODIFYING ANTI-RHEUMATIC DRUGS FOR TREATMENT OF RHEUMATOID ARTHRITIS: DATA FROM THE OBRI DATABASE}

Elliot Hepworth ${ }^{1}$, Mohammad Movahedi ${ }^{2}$, Emmanouil Rampakakis ${ }^{3}$, Reza Mirza ${ }^{1}$, Arthur Lau ${ }^{4}$, Angela Cesta ${ }^{2}$, Janet Pope ${ }^{5}$, Claire Bombardier, ${ }^{2,6} .{ }^{1}$ McMaster University, Internal Medicine, Hamillton, Canada; ${ }^{2}$ Toronto General Hospital Research Institute, University Health Network, Ontario Best Practices Research Initiative, Toronto, Canada; ${ }^{3}$ JSS Medical Research, St-Laurent-QC, Canada; ${ }^{4}$ McMaster University, Rheumatology, Hamillton, Canada; ${ }^{5}$ Western University, Divisions of Rheumatology, Epidemiology and Biostatistics, Department of Medicine, London, Canada; 6 University of Toronto, Mount Sinia Hospital, Rheumatology, Toronto, Canada

Background: For patients with Rheumatoid Arthritis (RA) who do not achieve adequate clinical response with combined conventional synthetic disease modifying anti-rheumatic drugs (csDMARDs), the next step in goal-directed therapy is initiation of either biologic DMARDs (bDMARDs) or targeted synthetic DMARDs (tsDMARDs). bDMARDs include tumournecrosis factor inhibitors (TNFi) or non-TNFi classes. Since inception of Ontario Best Practice Research Initiative (OBRI), new treatment options have become available

Objectives: We aimed to describe the evolution of relative use of nonTNFi vs. TNFi in Ontario-based practices from 2008-2017.

Methods: Adult patients with RA enrolled in the OBRI who started therapy with bDMARDs or tsDMARDs anytime during, or up to 30 days before, enrollment were included. Using descriptive analysis of data from each year between 2008 and 2017, the relative proportion of the population treated with TNFi and non-TNFi therapy was measured for (i) all patients and (ii) those initiating their first bDMARD/tsDMARD. TNFi included: Etanercept, Adalimumab, Certolizumab, Golimumab, and Infliximab. Non-TNFi included: Abatacept, Rituximab, Tocilizumab, and Tofacitinib.

Results: A total of 1,057 patients were included of whom 653 were bDMARD/tsDMARD naïve. In 2008, the relative non-TNFi use was $3 / 56$ $(5.4 \%)$ in all patients and $0 / 31(0 \%)$ in treatment-naïve patients. By 2013 the proportion non-TNFi use increased to $135 / 562(24 \%)$ in all patients and $11 / 92(12.0 \%)$ in treatment-naïve patients. This increasing trend in relative non-TNFi utilization continued in both groups until 2016 when relative use was $224 / 679(33.0 \%)$ in all patients and $17 / 56(30.4 \%)$ in treatment-naïve. This was followed by $144 / 426(33.8 \%)$ and $4 / 15(26.7 \%)$, respectively in 2017.

Conclusion: This descriptive analysis of data from the OBRI cohort shows an increase in the use of non-TNFi therapies. The overall trend towards greater use of non-TNFi therapies as first line agents after combined csDMARDs may be partially explained by the presence of guidelines that allow clinicians to select any of the above options as first line advanced therapies. Future analyses evaluating patient-, disease- and concomitant drug use-specific determinants of physician decision-making will be conducted.

Acknowledgement: Drs. Ahluwalia, V., Ahmad, Z., Akhavan, P., Albert, L., Alderdice, C., Aubrey, M., Aydin, S., Bajaj, S., Bensen, B., Bhavsar, S., Bobba, R., Bombardier, C., Bookman, A., Cabral, A., Carette, S., Carmona, R., Chow, A., Ciaschini, P., Cividino, A., Cohen, D., Dixit, S., Haaland, D., Hanna, B., Haroon, N., Hochman, J., Jaroszynska, A., Johnson, S., Joshi, R., Kagal, A., Karasik, A., Karsh, J., Keystone, E., Khalidi, N., Kuriya, B., Larche, M., Lau, A., LeRiche, N., Leung, Fe., Leung, Fr., Mahendira, D., Matsos, M., McDonald-Blumer, Midzic, I., Milman, N., H., Mittoo, S., Mody, A., Montgomery, A., Mulgund, M., Ng, E., Papneja, T., Pavlova, P., Perlin, L., Pope, J, Purvis, J., Rohekar, G., Rohekar, Ruban, T., S., Samadi, N., Shaikh, S., Shickh, A., Shupak, R., Smith, D., Soucy, E., Stein, J., Thompson, A., Thorne, C., Wilkinson, S.

Disclosure of Interests: Elliot Hepworth: None declared, Mohammad Movahedi: None declared, Emmanouil Rampakakis : None declared, Reza Mirza: None declared, Arthur Lau: None declared, Angela Cesta: None declared, Janet Pope Consultant for: Eli Lilly and Company, Claire Bombardier Grant/research support from: Abbvie, Amgen, Bristol-Myers Squibb, Celgene, Eli Lilly, Hospira, Janssen, Merck, Novartis, Pfizer Inc, Roche, Sanofi, UCB, Consultant for: AbbVie, Hospira, Janssen, Merck, Novartis, Pfizer Inc, Sanofi, Speakers bureau: Roche

DOI: 10.1136/annrheumdis-2019-eular.8100

\section{THU0164}

THE DAS28 BASED ON THE ERYTHROCYTE SEDIMENTATION RATE MAY OVERESTIMATE DISEASE ACTIVITY IN EARLY, TREATMENT-NAÏVE PATIENTS WITH RHEUMATOID ARTHRITIS WITH HIGH LEVELS OF RHEUMATOID FACTOR

Emanuele Bozzalla Cassione, Serena Bugatti, Francesca Benaglio,

Garifallia Sakellariou, Antonio Manzo, Roberto Caporali,

Carlomaurizio Montecucco. Division of Rheumatology, IRCCS Policlinico San

Matteo Foundation, University of Pavia, pavia, Italy

Background: Disease activity in rheumatoid arthritis (RA) is commonly measured with the DAS28-ESR. However, ESR levels may be affected by factors not related to inflammation leading to possible disparities with the DAS28CRP. In particular, increased levels of gammaglobulins may cause increase in ESR. In RA levels of autoantibodies such as rheumatoid factor (RF) and anti-citrullinated protein antibodies (ACPA) may be particularly high; however, their effect on the assessment of disease activity has not been investigated. Objectives: To evaluate whether positivity and levels of RF and ACPA determine discordance between the DAS28-ESR and the DAS28-CRP impacting on disease activity stratification in RA.

Methods: 578 early treatment-naïve RA patients (symptoms' duration $<12$ months) consecutively recruited at our Early Arthritis Clinic between 2005 and 2014 were studied. Paired DAS28-ESR and DAS28-CRP were obtained at baseline and after 6 months of therapy with conventional synthetic disease modifying anti-rheumatic drugs (csDMARDs). RF and ACPA were determined centrally on baseline sera, and levels were considered high when $>3$ times the upper limit of normal (ULN). Agreement between the disease activity scores was compared using Bland-Altman statistics before and after stratification for autoantibody-positivity and levels.

Results: Female/male ratio was 2.5:1, with mean (SD) age of 59.7 (14.8) years and median (IQR) symptoms' duration at inclusion of 15.6 (9.4 to 27.8) weeks. Mean DAS28-ESR values at baseline were 0.39 points higher compared to DAS28-CRP in the whole cohort, with more pronounced differences in females and subjects aged $>65$ years (Table 1). Collectively RF-positive patients had significantly higher discrepancies compared to -negative subjects (mean [SD] difference $0.45[0.46]$ vs 0.35 [0.47], $p=0.03$ ), particularly in females irrespective of age. The highest disagreement was recognized in patients with high autoantibody levels; females with RF $>3$ ULN had DAS28-ESR scores 0.56 points higher Disparities in these patients impacted on disease activity stratification, as more RF-high females were in DAS28-ESR high disease activity compared with DAS28-CRP $(43.1 \%$ vs $23 \%, p<0.001)$. In contrast, ACPA-positivity did not affect the agreement between the two disease activity indices (Table 1). After 6 months of treatment with csDMARDs discrepancies between the DAS28-ESR and DAS28-CRP in RF-positive patients was reduced but still significant in association with levels $>3$ ULN (mean difference $[95 \% \mathrm{Cl}] 0.44[0.33-0.55])$.

Conclusion: In patients with early treatment-naïve RA, the DAS28-ESR and DAS28-CRP are not inter-exchangeable. In particular, the DAS28-ESR may overestimate disease activity when levels of RF are high. These findings suggest that disease assessment for treat-to-target approaches should take into account additional factors such as autoantibody-positivity.

Abstract THU0164 -Table 1. Comparative mean differences (95\% Cl) between DAS28ESR and DAS28-CRP stratified for autoantibodies

\begin{tabular}{lccccc}
\hline & $\begin{array}{c}\text { whole } \\
\text { cohort }\end{array}$ & female & male & $\begin{array}{c}\text { age } \geq 65 \\
\text { years }\end{array}$ & $\begin{array}{c}\text { age }<65 \\
\text { years }\end{array}$ \\
\hline overall & $0.39(0.35-$ & $0.44(0.47-$ & $0.26(0.18-$ & $0.42(0.36-$ & $0.37(0.31-$ \\
& $0.43)$ & $0.50)$ & $0.34)$ & $0.49)$ & $0.43)$ \\
RF-pos & $0.45(0.38-$ & $0.52(0.43-$ & $0.26(0.13-$ & $0.47(0.33-$ & $0.46(0.37-$ \\
& $0.53)$ & $0.61)$ & $0.39)$ & $0.61)$ & $0.55)$ \\
RF-pos $>3$ & $0.50(0.40-$ & $0.56(0.45-$ & $0.29(0.10-$ & $0.51(0.30-$ & $0.51(0.39-$ \\
ULN & $0.60)$ & $0.68)$ & $0.49)$ & $0.72)$ & $0.62)$ \\
ACPA-pos & $0.41(0.34-$ & $0.49(0.41-$ & $0.20(0.07-$ & $0.46(0.32-$ & $0.40(0.31-$ \\
& $0.48)$ & $0.57)$ & $0.34)$ & $0.58)$ & $0.49)$ \\
ACPA-pos $>3$ & $0.41(0.33-$ & $0.47(0.39-$ & $0.25(0.12-$ & $0.42(0.27-$ & $0.41(0.32-$ \\
ULN & $0.48)$ & $0.56)$ & $0.38)$ & $0.56)$ & $0.50)$ \\
ACPA- & $0.39(0.30-$ & $0.44(0.33-$ & $0.27(0.10-$ & $0.42(0.22-$ & $0.39(0.28-$ \\
pos $>100 \mathrm{U}$ & $0.49)$ & $0.56)$ & $0.44)$ & $0.61)$ & $0.51)$ \\
\hline
\end{tabular}

Disclosure of Interests: Emanuele Bozzalla Cassione: None declared, Serena Bugatti Speakers bureau: Bristol-Myers Squibb, Celgene, Lilly, Novartis, Sanofi, Janssen, Francesca Benaglio: None declared, Garifallia Sakellariou: None declared, Antonio Manzo: None declared, Roberto Caporali Speakers bureau: AbbVie, Bristol-Myers Squibb, Celgene, Roche, Genzyme, Lilly, MSD, Pfizer, UCB, Carlomaurizio Montecucco Speakers bureau: AbbVie Bristol-Myers Squibb, Celgene, Sanofi, Genzyme, Lilly, MSD, Pfizer, UCB DOI: 10.1136/annrheumdis-2019-eular.6230 